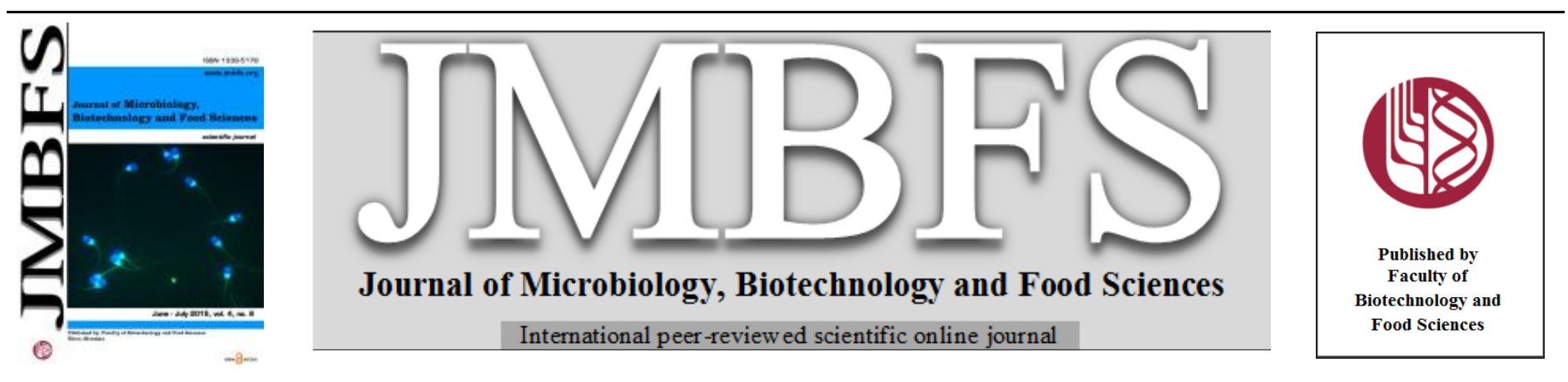

\title{
MECHANISM OF FUSARIUM TRICINCTUM (CORDA) SACC. SPORE INACTIVATION BY CHLORINE DIOXIDE
}

\section{Zhao Chen* ${ }^{1,2}$}

\author{
Address(es): \\ ${ }^{1}$ Deapartment of Biological Sciences, College of Agriculture, Forestry and Life Sciences, Clemson University, Clemson, SC 29634, US \\ ${ }^{2}$ Department of Microbiology, College of Life Sciences, Shandong Agricultural University, Taian, Shandong 271018, China
}

*Corresponding author: zchen5@clemson.edu

doi: 10.15414/jmbfs.2015.4.6.542-545

\section{ARTICLE INFO}

Received 6. 3. 2015

Revised 31. 3. 2015

Accepted 6. 4. 2015

Published 1. 6. 2015

\section{Regular article}

OPEN OACCESS

\begin{abstract}
The mechanism of Fusarium tricinctum (Corda) Sacc. spore inactivation by chlorine dioxide $\left(\mathrm{ClO}_{2}\right)$ was investigated. During $F$. tricinctum spore inactivation by $\mathrm{ClO}_{2}$, protein, DNA, and metal ion leakage, enzyme activity, and cell ultrastructure were examined. Protein and DNA leakages were not detected, while there were metal ion leakages of $\mathrm{K}^{+}, \mathrm{Ca}^{2+}$ and $\mathrm{Mg}^{2+}$, which were well-correlated with the inactivation rate. The enzyme activities of glucose-6-phosphate dehydrogenase, citrate synthase, and phosphofructokinase were inhibited and were also well-correlated with the inactivation rate. Electron micrographs showed the ultrastructural modifications of spores and demonstrated that spores were heavily distorted and collapsed from their regular structure. Spore surface damage and disruption in inner components was also severe. The metal ion leakage, the inhibition of enzyme activities, and the damage of spore structure were significant in $F$. tricinctum spore inactivation by $\mathrm{ClO}_{2}$.
\end{abstract}

Keywords: Chlorine dioxide, mechanism, inactivation, Fusarium tricinctum (Corda) Sacc., spore

\section{INTRODUCTION}

Chlorine dioxide $\left(\mathrm{ClO}_{2}\right)$ is an effective disinfectant that has broad and high germicidal activity. It is more stable and has a higher oxidizing capability as compared to chlorine (Chen et al., 2010). Numerous studies have been carried out to prove the effective inactivation of various microorganisms by $\mathrm{ClO}_{2}$ (Gómez-López et al., 2009; Chen et al., 2010; Chen and Zhu, 2011a; Chen and Zhu, 2011b; Zhu et al., 2012). Nevertheless, the mechanism of microbial inactivation by $\mathrm{ClO}_{2}$ has not been clearly clarified as lethal incidences are usually associated with complicated processes. Some authors have attempted to elucidate the biocidal mechanisms of $\mathrm{ClO}_{2}$ and have concluded that $\mathrm{ClO}_{2}$ could cause series of damage, such as content leakage (Zhang et al., 2007; Wei et al., 2008) protein and nucleic acid denaturation (Hauchman et al., 1986; Noss et al., 1986; Li et al., 2004; Cho et al., 2010; Simonet and Gantzer, 2006), and morphological alteration (Chen et al., 2002; Wang et al., 2010). However, there is still a lack of understanding on the major target site of $\mathrm{ClO}_{2}$ interaction with microorganisms. Moreover, most of the published studies deal with inactivation mechanisms of $\mathrm{ClO}_{2}$ on bacteria and viruses. Our previous study has showed that the metal ion leakage, the inhibition of enzyme activities, and the alteration of cell structure were critical events in Saccharomyces cerevisiae inactivation by $\mathrm{ClO}_{2}$ (Zhu et al., 2012). The objective of this research was thus to investigate the inactivation mechanism of $\mathrm{ClO}_{2}$ on Fusarium tricinctum (Corda) Sacc. spore. Thorough investigations, including leakages of protein, DNA, and metal ion, enzyme activity, and spore ultrastructure, were performed to evaluate whether they were correlated with the inactivation rate. This is the first study on the inactivation mechanism of $\mathrm{ClO}_{2}$ on fungal spores.

\section{MATERIAL AND METHODS}

\section{Fungal spore suspension}

Fusarium tricinctum (Corda) Sacc. was isolated from naturally infected chestnuts and identified based on morphological and physiological tests (Wei, 1979). Spores were cultivated and collected as described previously (Chen $\boldsymbol{e t ~ a l . , 2 0 1 1 ) .}$ The final pellet was resuspended in sterile saline. The concentration of spores was determined in a Neubauer counting chamber and the initial concentration was adjusted to approx. $1 \times 10^{9} \mathrm{CFU} / \mathrm{ml}$.

\section{$\mathrm{ClO}_{2}$ solution}

A commercially available product of stabilized $\mathrm{ClO}_{2}$ powder (Charmstar, Tianjin Charmstar Technology Development Co., Ltd., Tianjin, China) was dissolved in deionized water to prepare a stock solution (approx. $500 \mathrm{mg} / \mathrm{L}$ ) according to the manufacturer's instructions. The $\mathrm{ClO}_{2}$ concentration was accurately measured by a standard method using iodimetry right before use (APHA, 1998). Then the stock solution was further diluted with deionized water to prepare solutions with desired concentrations.

\section{$\mathrm{ClO}_{2}$ treatment}

In concentration-dependent inactivation experiment, $5 \mathrm{ml}$ of spore suspension was treated with equal volumes of $\mathrm{ClO}_{2}$ with final concentrations of $1,2,4,5,10$, 20,50 , and $100 \mathrm{mg} / \mathrm{L} \mathrm{ClO}_{2}$ for $1 \mathrm{~min}$; in time-dependent inactivation experiment, $5 \mathrm{ml}$ of spore suspensions was treated with equal volumes of $\mathrm{ClO}_{2}$ with final concentration of $4 \mathrm{mg} / \mathrm{L}$ for $1,5,10,15,20,25,30$, and $60 \mathrm{~min}$. Immediately after each treatment, $5 \mathrm{ml}$ of cell suspensions was transferred to a $5 \mathrm{ml}$ of sterile neutralizing phosphate buffer (containing $0.5 \%$ sodium thiosulfate, $\mathrm{pH} 7.2$ ) to neutralize the residual $\mathrm{ClO}_{2}$ to terminate the inactivation process. The spores treated by sterile deionized water were used as the control.

\section{Determination of inactivation rate}

After neutralization, serial 10 -fold dilutions were prepared in sterile saline Diluents were spread on dichloran glycerol (DG-18) agar and colonies were counted and results expressed as $\log \mathrm{cfu} / \mathrm{ml}$ after incubation at $30^{\circ} \mathrm{C}$ for $3 \mathrm{~d}$. The initial spore populations before treatments were also counted. Inactivation rate was then determined. The minimal fungicidal $\mathrm{ClO}_{2}$ concentration and treatment time were defined as the minimal $\mathrm{ClO}_{2}$ concentration and treatment time producing 99.9\% inactivation rate, respectively (Zhu et al., 2012).

\section{Measurement of intracellular content leakage}

After neutralization, the mixture was centrifuged at $3,000 \times g$ for $10 \mathrm{~min}$ at $4^{\circ} \mathrm{C}$ Afterwards, the supernatants were collected for the determination of intracellular content leakage. The protein content was measured at $595 \mathrm{~nm}$ by Bradford method using bovine serum albumin as the standard (Bradford, 1976), while the DNA content was measured at $280 \mathrm{~nm}$ using bovine thymus DNA as the standard (Chen et al., 2002). The metal ion $\left(\mathrm{K}^{+}, \mathrm{Ca}^{2+}\right.$, and $\left.\mathrm{Mg}^{2+}\right)$ contents were 
determined by using ICP-MS (VISTA-PRO, Varian, Varian Medical Systems, Inc., Palo Alto, CA, USA).

\section{Measurement of enzyme activity}

After neutralization, the mixture was centrifuged at $3,000 \times \mathrm{g}$ for $10 \mathrm{~min}$ at $4^{\circ} \mathrm{C}$ and the pellets suspended in $5 \mathrm{ml}$ of $0.05 \mathrm{~mol} / \mathrm{L}$ Tris- $\mathrm{HCl}$ buffer $(\mathrm{pH} 7.5$ ). Suspended spores were then disrupted by submitting them to a vortex for $5 \mathrm{~min}$, in the presence of $5 \mathrm{~g}$ of glass beads $(0.5 \mathrm{~mm}$ diameter). The disruption period was 1 min separated by $30 \mathrm{~s}$ interval in an ice bath. Cell debris and glass beads were then removed by centrifugation at $3000 \times \mathrm{g}$ for $10 \mathrm{~min}$ at $4^{\circ} \mathrm{C}$ and the supernatant was used for the determination of enzyme activities.

The glucose-6-phosphate dehydrogenase (G6PD) activity was measured by spectrophotometry at $30^{\circ} \mathrm{C}$ and $340 \mathrm{~nm}$ using $\mathrm{NADP}^{+}$as cofactor (Gurpilhares et al., 2006). G6PD activity was determined in a medium composed by: $500 \mu \mathrm{l}$ Tris- $\mathrm{HCl}$ buffer $(0.05 \mathrm{~mol} / \mathrm{L}, \mathrm{pH} 7.5), 100 \mu 1 \mathrm{MgCl}_{2}(0.035 \mathrm{~mol} / \mathrm{L}), 5 \mu 1 \mathrm{NADP}^{+}$ $(0.131 \mathrm{~mol} / \mathrm{L}), 10 \mu \mathrm{G} 6 \mathrm{P}(0.5 \mathrm{~mol} / \mathrm{L})$ and $100 \mu \mathrm{l}$ of sample. The citrate synthase (CS) activity was determined at $30^{\circ} \mathrm{C}$ and $412 \mathrm{~nm}$ using $520 \mu 1$ buffer $(50$ $\mathrm{mmol} / \mathrm{L}$ Tris- $\mathrm{HCl}$ containing $100 \mathrm{mmol} / \mathrm{L} \mathrm{KCl}$ and $1 \mathrm{mmol} / \mathrm{L}$ EDTA, $\mathrm{pH}$ 7.5), 20 $\mu 1 \mathrm{DTNB}, 20 \mu \mathrm{l}$ acetyl coenzyme A $(2.5 \mathrm{mmol} / \mathrm{L}$ in distilled water $), 20 \mu \mathrm{l}$ oxaloacetate $(5.0 \mathrm{mmol} / \mathrm{L}$ in distilled water), and $20 \mu \mathrm{l}$ of the sample (Lemos $\boldsymbol{e}$ al., 2003). The phosphofructokinase (PFK) activity was assayed spectrophotometrically by monitoring the change of absorbance at $340 \mathrm{~nm}$ and $30^{\circ} \mathrm{C}$ (Gancedo and Gancedo, 1971). The assay was performed in $1 \mathrm{ml}$ mixture of the following composition: $0.05 \mathrm{~mol} / \mathrm{L}$ Tris- $\mathrm{HCl}$ buffer, $\mathrm{pH} 7.5,0.05 \mathrm{mmol} / \mathrm{L}$ ATP, $5 \mathrm{mmol} / \mathrm{L} \mathrm{MgCl}_{2}, 0.125 \mathrm{mmol} / \mathrm{L} \mathrm{NADH}, 0.25 \mathrm{mmol} / \mathrm{L}$ F6P, 0.5 units of aldolase, glycerophosphate dehydrogenase, and triosephosphate isomerase. One unit of enzyme activity (U) was defined as the quantity of enzyme catalyzing the conversion of $1 \mu \mathrm{mol}$ of substrate per min. Specific activity was expressed as units per milligram of total protein. Total protein concentration was measured by Bradford method using bovine serum albumin as the standard.

\section{Microscopic analysis of spore ultrastructure}

Spore ultrastructures of control, spores treated with $5 \mathrm{mg} / \mathrm{L} \mathrm{ClO} 2$ for $1 \mathrm{~min}$, and spores treated with $4 \mathrm{mg} / \mathrm{L} \mathrm{ClO}_{2}$ for 10 min were examined using a transmission electron microscope (JEM-1200EX, JEOL, JEOL Ltd., Tokyo, Japan).

\section{Statistical analysis}

All experiments were carried out in three trials. Data were analyzed using SigmaPlot 12.0 (Systat Software Inc., San Jose, CA, USA).

\section{RESULTS}
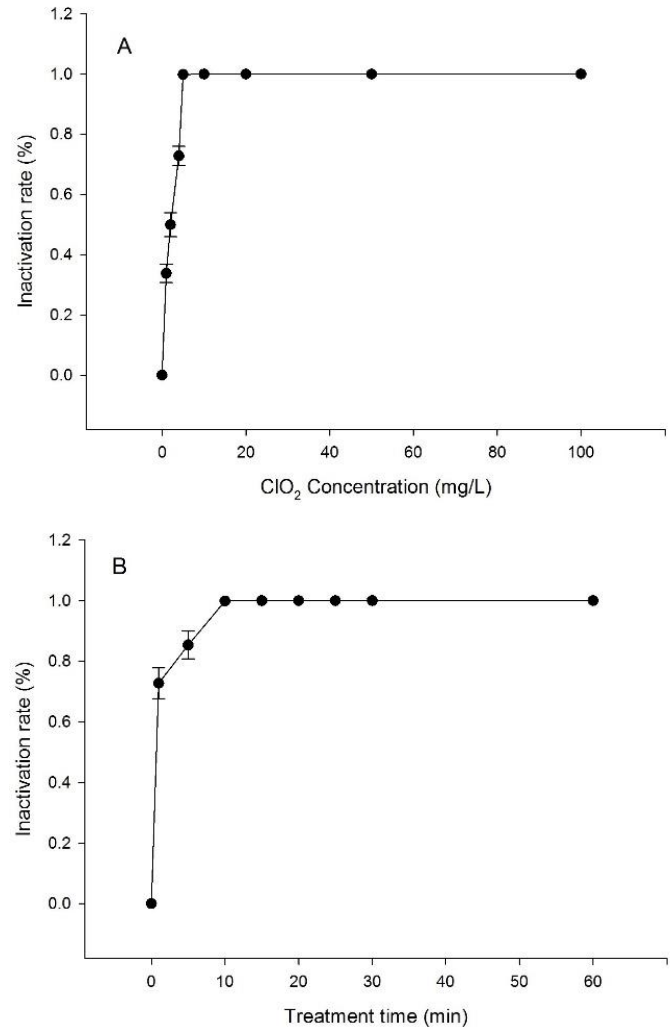

Figure 1 Inactivation rates of $F$. tricinctum spores treated by $\mathrm{ClO}_{2}$ with different concentrations (A) and treatment times (B). Vertical bars indicate standard deviation.
As shown in Fig. 1, the inactivation rate of $F$. tricinctum spores increased gradually, as $\mathrm{ClO}_{2}$ concentration increased from 0 to $5 \mathrm{mg} / \mathrm{L}$ and treatment time extended from 0 to $10 \mathrm{~min}$. And when $\mathrm{ClO}_{2}$ concentration increased to $5 \mathrm{mg} / \mathrm{L}$ and treatment time prolonged to $10 \mathrm{~min}$, the inactivation rate reached up to $99.9 \%$. Afterwards, the inactivation rate maintained at $100 \%$. The minimal fungicidal $\mathrm{ClO}_{2}$ concentration and treatment time were $5 \mathrm{mg} / \mathrm{L}$ and $10 \mathrm{~min}$, respectively.
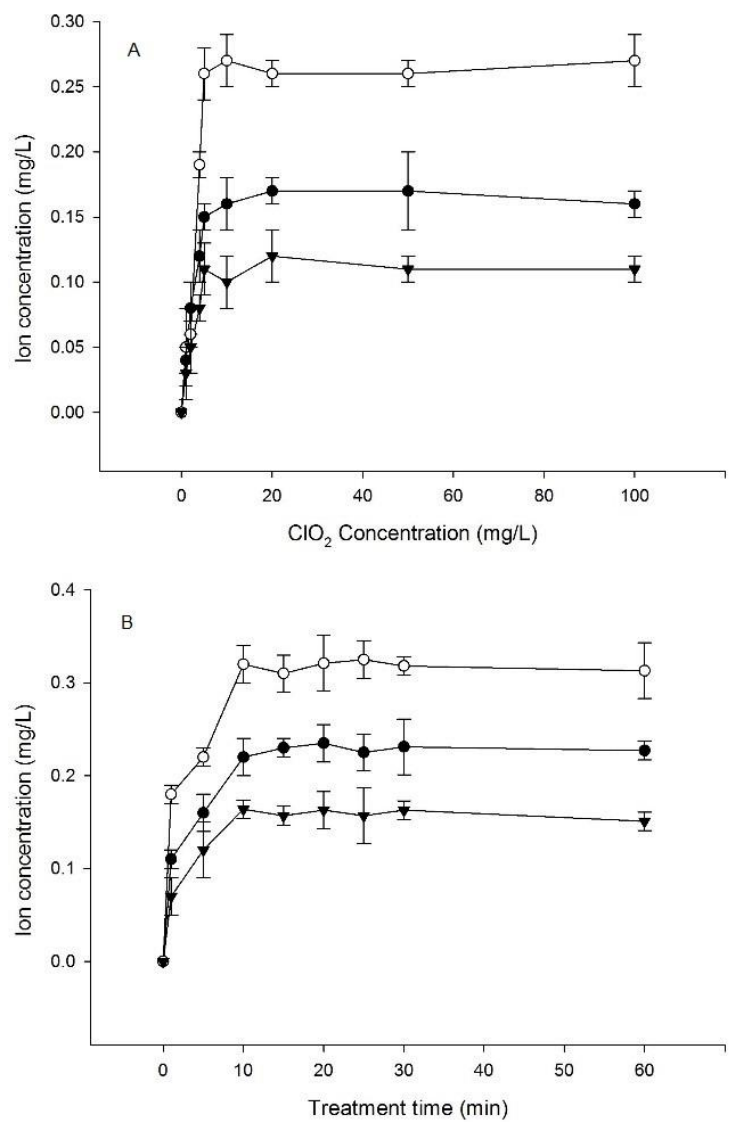

Figure 2 Metal ion leakages of $F$. tricinctum spores treated by $\mathrm{ClO}_{2}$ with different concentrations (A) and treatment times (B). Vertical bars indicate standard deviation. $(\boldsymbol{\nabla}), \mathrm{K}^{+} ;(\circ), \mathrm{Ca}^{2+} ;(\bullet), \mathrm{Mg}^{2+}$.

In the present study, there were no detectable protein and DNA leakages in $F$. tricinctum spore, regardless of $\mathrm{ClO}_{2}$ concentration or treatment time. In consideration of the fact that protein and DNA are macromolecules, they might not leak out of the cell readily. In despite of no detectable protein or DNA leakage, we could not draw the conclusion that cell membranes were not permeated by $\mathrm{ClO}_{2}$, since metal ions, including $\mathrm{K}^{+}, \mathrm{Ca}^{2+}$, and $\mathrm{Mg}^{2+}$, showed different levels of leakage (Fig. 2). The leakages of $\mathrm{K}^{+}, \mathrm{Ca}^{2+}$, and $\mathrm{Mg}^{2+}$ displayed gradual increase before $99.9 \%$ of the spores were inactivated. Afterwards, although $\mathrm{ClO}_{2}$ concentration and treatment time continued to increase, no significant increase in metal ion leakage was detected. Similarly, Wang et al. (2010) also found that the content of $\mathrm{K}^{+}, \mathrm{Ca}^{2+}$, and $\mathrm{Mg}^{2+}$ in Nosema bombycis spore was lost immediately after the $50 \mathrm{mg} / \mathrm{L} \mathrm{ClO}_{2}$ treatment. Moreover, they also indicated that a large amount of protein and DNA of the spores leaked out in a short time after the $50 \mathrm{mg} / \mathrm{L} \mathrm{ClO}_{2}$ treatment. The difference between our results and theirs may attribute to the different biological responses of different organisms to $\mathrm{ClO}_{2}$ treatment. Hence, it is essential to investigate the biocidal mechanisms of $\mathrm{ClO}_{2}$ on various species of organisms, since results obtained from one organism may not be generalized to others.

Table 1 Correlation between inactivation rates of $F$. tricinctum spores treated by $\mathrm{ClO}_{2}$ with different concentrations and metal ion leakages

\begin{tabular}{lccc}
\hline \multirow{2}{*}{ Correlation } & \multicolumn{3}{c}{ Metal ion leakage } \\
\cline { 2 - 4 } & $\mathrm{K}^{+}$ & $\mathrm{Ca}^{2+}$ & $\mathrm{Mg}^{2+}$ \\
\hline$R^{2}$ & 0.90 & 0.88 & 0.87 \\
\hline
\end{tabular}

Table 2 Correlation between inactivation rates of $F$. tricinctum spores treated by $\mathrm{ClO}_{2}$ with different treatment times and metal ion leakages

\begin{tabular}{lccc}
\hline \multirow{2}{*}{ Correlation } & \multicolumn{3}{c}{ Metal ion leakage } \\
\cline { 2 - 4 } & $\mathrm{K}^{+}$ & $\mathrm{Ca}^{2+}$ & $\mathrm{Mg}^{2+}$ \\
\hline$R^{2}$ & 0.89 & 0.86 & 0.85 \\
\hline
\end{tabular}


More importantly, the inactivation rate of $F$. tricinctum spores treated by $\mathrm{ClO}_{2}$ with different concentrations was well-correlated with metal ion leakages (Table 1 and 2).
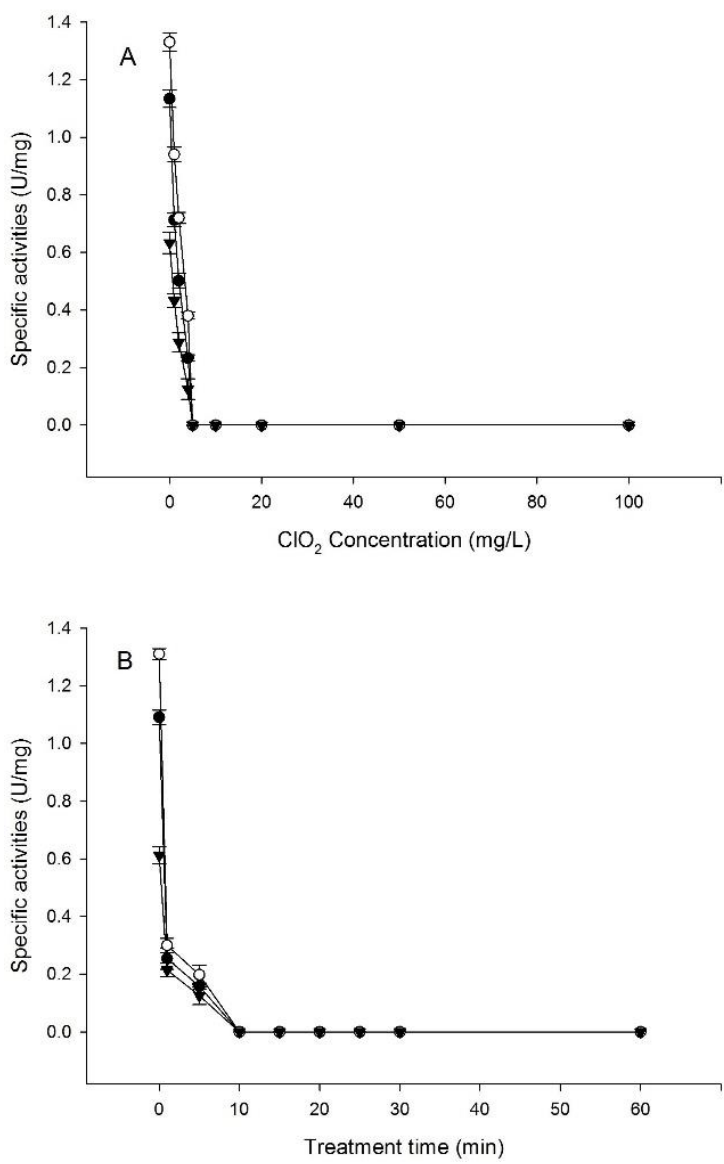

Figure 3 Enzyme activities of $F$. tricinctum spores treated by $\mathrm{ClO}_{2}$ with differen concentrations (A) and treatment times (B). Vertical bars indicate standard deviation. (•), G6PD; (०),CS; and ( $\boldsymbol{\nabla})$, PFK.

G6PD catalyzes the oxidation of glucose-6-phosphate to form 6-phosphoglucono$\delta$-lactone in the pentose phosphate pathway (PPP), which produces NADPH (Nelson and Cox, 2012). CS catalyzes the condensation of acetyl-CoA with oxaloacetate to form citrate, which is the first reaction of tricarboxylic acid (TCA) cycle. PFK catalyzes the transfer of a phosphoryl group from ATP to fructose-6-phosphate to yield fructose-1,6-bisphosphate. As shown in Fig. 3, $\mathrm{ClO}_{2}$ dramatically inhibited the enzyme activities of G6PD, CS, and PFK in $F$. tricinctum spores. Inhibition of enzyme activities became more obvious when $\mathrm{ClO}_{2}$ concentration increased from 0 to $100 \mathrm{mg} / \mathrm{L}$ and treatment time extended from 0 to $60 \mathrm{~min}$. The enzyme activities of G6PD, CS, and PFK were completely inhibited when inactivation rate reached $99.9 \%$. After enzyme activities decreased to $0 \mathrm{U} / \mathrm{mg}$, they remained inhibited for the rest of the time.

Table 3 Correlation between inactivation rates of $F$. tricinctum spores treated by $\mathrm{ClO}_{2}$ with different concentrations and enzyme activities

\begin{tabular}{lccc}
\hline \multirow{2}{*}{ Correlation } & \multicolumn{3}{c}{ Enzyme activity } \\
\cline { 2 - 4 } & $\mathrm{G6PD}^{\mathrm{a}}$ & $\mathrm{CS}^{\mathrm{b}}$ & $\mathrm{PFK}^{\mathrm{c}}$ \\
\hline$R^{2}$ & 0.85 & 0.86 & 0.88 \\
\hline
\end{tabular}

Legend: ${ }^{a}$ Glucose-6-phosphate dehydrogenase.

${ }^{\mathrm{b}}$ Citrate synthase.

${ }^{\mathrm{c}}$ Phosphofructokinase.

Table 4 Correlation between inactivation rates of $F$. tricinctum spores treated by $\mathrm{ClO}_{2}$ with different treatment times and enzyme activities

\begin{tabular}{|c|c|c|c|}
\hline \multirow{2}{*}{ Correlation } & \multicolumn{3}{|c|}{ Enzyme activity } \\
\hline & G6PD $^{\mathrm{a}}$ & $\mathrm{CS}^{\mathrm{b}}$ & $\overline{\mathrm{PFK}^{\mathrm{c}}}$ \\
\hline$R^{2}$ & 0.87 & 0.90 & 0.88 \\
\hline
\end{tabular}

Legend: ${ }^{\mathrm{a}}$ Glucose-6-phosphate dehydrogenase.

${ }^{\mathrm{b} C i t r a t e}$ synthase.

${ }^{\mathrm{c}}$ Phosphofructokinase.

More importantly, the inactivation rate of $F$. tricinctum spores treated by $\mathrm{ClO}_{2}$ with different concentrations was well-correlated with enzyme activities (Table 3 and 4). Therefore, it can be speculated that $\mathrm{ClO}_{2}$ penetrated into $F$. tricinctum spore and damaged the structures of enzymes, which had negative influences on some critical microbial metabolic processes. And noticeably, the inhibition of enzyme activity was correlated with the metal ion leakage. It should be due to the fact that some enzymes require an additional chemical component such as metal ion called a cofactor for activity (Zhu et al., 2012).

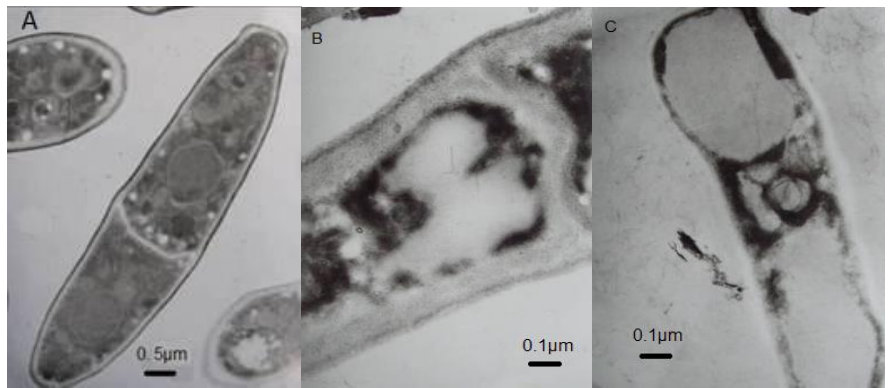

Figure 4 Ultrastructures of normal $F$. tricinctum spore (A), spore treated by 5 $\mathrm{mg} / \mathrm{L}$ chlorine dioxide for $1 \mathrm{~min}(\mathrm{~B})$, and spore treated by $4 \mathrm{mg} / \mathrm{L}$ chlorine dioxide for $10 \mathrm{~min}$.

Fig. 4A shows a normal canoe-shaped spore structure, which had a clear observation of plasma membrane and intracellular contents divided by a crosswall. After the treatments of $5 \mathrm{mg} / \mathrm{L}$ chlorine dioxide for $1 \mathrm{~min}$ and $4 \mathrm{mg} / \mathrm{L}$ chlorine dioxide for $10 \mathrm{~min}(99.9 \%$ of the cells were inactivated), membrane structure was damaged, cytoplasm was pycnotic, and organelles could not be identified (Fig. 4B and 4C). Severe damage on intracellular components, such as visible holes in the cytoplasm, were also observed. Some authors also reported that $\mathrm{ClO}_{2}$ could cause morphological alteration for different microorganisms. Ou results were consistent with Cho et al. (2010) who reported that Escherichia coli cell showed partial damages for both cell surfaces and intracellular components after inactivation by $\mathrm{ClO}_{2}$. However, our findings were in contrast with Wei et al. (2008) who studied the inactivation mechanism of $\mathrm{ClO}_{2}$ on Candida albicans. They observed no obvious damage on the plasma membranes and inner structures. And the cell wall was even found to be intact when the cell was inactivated. Nonetheless, they reported that the cytoplasm appeared a little 'rougher' and the cell wall became less dense after $\mathrm{ClO}_{2}$ treatment. The differences among studies may be explained by the different responses of microbial cells to $\mathrm{ClO}_{2}$ treatment.

\section{CONCLUSION}

The protein and DNA leakages were not correlated with the inactivation rate of $F$. tricinctum spore; however, the mechanism of $F$. tricinctum spore inactivation by $\mathrm{ClO}_{2}$ is linked to the leakages of $\mathrm{K}^{+}, \mathrm{Ca}^{2+}$, and $\mathrm{Mg}^{2+}$, the inhibition of key enzyme activities in some major metabolic pathways, and the damage of spore structure.

\section{REFERENCES}

Paidhungat, M. and Setlow, P. (2000) Role of Ger proteins in nutrient and non-nutrient triggering of spore germination in Bacillus subtilis. Journal of Bacteriology 182, 2513-2519.

AMERICAN PUBLIC HEALTH ASSOCIATION (APHA). 1998. Standard Methods for the Examination of Water and Waste Water.

BRADFORD, M.M. 1976. A rapid and sensitive method for the quantitation of microgam quantities of protein utilizing the principle of protein-dye binding Analytical Biochemistry, 72, 248-254. http://dx.doi.org/10.1016/0003 2697(76)90527-3

CHEN, C., LI, D., LIU, X., BAO, L., LIU, Z. 2002. Experimental observation on mechanism of bactericidal effect of chlorine dioxide. Chinese Journal of Disinfection, 19, 137-141. $\quad$ http://dx.doi.org/10.3969/j.issn.10017658.2002.03.001

CHEN, Z., ZHU, C., ZHANG, Y., NIU, D., DU, J. 2010. Effects of aqueous chlorine dioxide treatment on enzymatic browning and shelf-life of fresh-cut asparagus lettuce (Lactuca sativa L.). Postharvest Biology and Technology, 58, 232-238. http://dx.doi.org/10.1016/j.postharvbio.2010.06.004

CHEN, Z., ZHU, C., HAN, Z. 2011. Effects of aqueous chlorine dioxide treatment on nutritional components and shelf-life of mulberry fruit (Morus alba L.). Journal of Bioscience and Bioengineering, 111, 675-681. http://dx.doi.org/10.1016/j.jbiosc.2011.01.010

CHEN, Z., ZHU, C. 2011a. Combined effects of aqueous chlorine dioxide and ultrasonic treatments on postharvest storage quality of plum fruit (Prunus salicina L.). Postharvest Biology and Technology, 61, 117-123. http://dx.doi.org/10.1016/j.postharvbio.2011.03.006

CHEN, Z., ZHU, C. 2011b. Modelling inactivation by aqueous chlorine dioxide of Dothiorella gregaria Sacc. and Fusarium tricinctum (Corda) Sacc. spores 
inoculated on fresh chestnut kernel. Letters in Applied Microbiology, 52, 676684. http://dx.doi.org/10.1111/j.1472-765X.2011.03061.x

CHO, M., KIM, J., KIM, J.Y., YOON, J., KIM, J. 2010. Mechanisms of Escherichia coli inactivation by several disinfectants. Water Research, 44, 34103418. http://dx.doi.org/10.1016/i.watres.2010.03.017

GANCEDO, J.M., GANCEDO, C. 1971. Fructose-1,6-diphosphatase, phosphofructokinase and ghcose-6-phosphate dehydrogenase from fermenting and non fermenting yeasts. Archiv für Mikrobiologie, 76, 132-138. http://dx.doi.org/10.1007/BF00411787

GÓMEZ-LÓPEZ, VM, RAJKOVIC A, RAGAERT P, SMIGIC N, DEVLIEGHERE F. 2009. Chlorine dioxide for minimally processed produce preservation: a review. Trends in Food Science and Technology, 20, 7-26. http://dx.doi.org/10.1016/j.tifs.2008.09.005

GURPILHARES, D.B., HASMANN, F.A., PESSOA, JR. A., ROBERTO, I.C. 2006. Optimization of glucose-6-phosphate dehydrogenase releasing from Candida guilliermondii by disruption with glass beads. Enzyme and Microbial Technology, 39, 591-595. http://dx.doi.org/10.1016/j.enzmictec.2005.11.018

HAUCHMAN, F.S., NOSS, C.I., OLIVIERI, V.P. 1986. Chlorine dioxide reactivity with nucleic acids. Water Research, 20, 357-361. http://dx.doi.org/10.1016/0043-1354(86)90084-9

LEMOS, D., SALOMON, M., GOMES, V., PHAN, V.N., BUCHHOLZ, F. 2003. Citrate synthase and pyruvate kinase activities during early life stages of the shrimp Farfantepenaeus paulensis (Crustacea, Decapoda, Penaeidae): effects of development and temperature. Comparative Biochemistry and Physiology Part B: Biochemistry and Molecular Biology, 135, 707-719. http://dx.doi.org/10.1016/S1096-4959(03)00166-0

LI, J.W., XIN, Z.T., WANG, X.W., ZHENG, J. L., CHAO, F.H. 2004 Mechanisms of inactivation of hepatitis A virus in water by chlorine dioxide. Water Research, 38, 1514-1519. http://dx.doi.org/10.1016/j.watres.2003.12.021

NELSON, D.L., COX, M.M. 2012. Lehninger Principles of Biochemistry, Sixth edition. New York: W. H. Freeman \& Co. p. 190-237. ISBN 978-1429234146.

NOSS, C.I., HAUCHMAN, F.S., OLIVIERI, V.P. 1986. Chlorine dioxide reactivity with proteins. Water Research, 20, 351-356. http://dx.doi.org/10.1016/0043-1354(86)90083-7

SIMONET, J., GANTZER, C. 2006. Degradation of the Poliovirus 1 genome by chlorine dioxide. Journal of Applied Microbiology, 100, 862-870. http://dx.doi.org/10.1111/j.1365-2672.2005.02850.x

WANG, Z., LIAO, F., LIN, J., LI, W., ZHONG, Y., TAN, P., HUANG, Z. 2010 Inactivation and mechanisms of chlorine dioxide on Nosema bombycis. Journal of Invertebrate Pathology, 104, 134-139. http://dx.doi.org/10.1016/j.jip.2009.11.007

WEI, J. 1979. Manual of Fungal Identification. Shanghai Science and Technology Press.

WEI, M.-K., WU, Q.-P., HUANG, Q., WU, J.-L. ZHANG, J.-M. 2008. Plasma membrane damage to Candida albicans caused by chlorine dioxide $\left(\mathrm{ClO}_{2}\right)$. Letters in Applied Microbiology, 47, 67-73. http://dx.doi.org/10.1111/j.1472 765X.2008.02387.X

ZHANG, X., WU, Q., ZHANG, J., WU, H., QUE, S. 2007. Study on mechanism of effect of chlorine dioxide on Escherichia coli. Chinese Journal of Disinfection, 24, 16-20. http://dx.doi.org/10.3969/j.issn.1001-7658.2007.01.005

ZHU, C., CHEN, Z., YU, G. 2012. Fungicidal mechanism of chlorine dioxide on Saccharomyces cerevisiae. Annals of Microbiology, 63, 495- 502 http://dx.doi.org/10.1007/s13213-012-0494-8 